KEYWORDS

Education

Educational policy

Educational reform

Educational quality

Public schools

Private schools

Measurement

Statistical methodology

Chile
José Luis Drago

School of Engineering, Catholic

University of Chile

- jldrago@uc.cl

Ricardo D. Paredes

Professor, School of Engineering,

Catholic University of Chile, and

Centre for the Study of Educational

Policy and Practice (CEPPE)

œrparedes@ing.puc.cl
CEPAL REVIEW 104 - AUGUST 2011

\section{The quality gap in Chile's education system}

\author{
José Luis Drago and Ricardo D. Paredes
}

$\mathrm{T}$

he quality gap in education between Chilean schools with different administrative structures (especially in the case of municipal schools and private subsidized schools) has long been a subject of analysis and discussion within the wider debate surrounding the relative efficiency and role of public education. Unconditioned differences in the results of standardized tests that point to higher levels of quality in private schools diminish when sociodemographic factors are controlled for, but the question as to what control variables should be used and which methodology is the most appropriate, as well as the extent of the reduction, all continue to be a subject of debate. Here we undertake a meta-analysis of 17 of the main studies that have been done on the subject. The analysis shows how sensitive the results are to the controls and estimation methods that are used. In the aggregate, private subsidized schools score approximately four points higher than municipal schools do. This is a statistically significant and educationally relevant differential. 


\section{I}

\section{Introduction}

Chile's reform of its education system in the 1980s and, in particular, its introduction of a large-scale voucher scheme were designed to decentralize the system and to promote competition among publicly funded schools as a means of improving the quality of instruction (Aedo and Sapelli, 2001; Mizala, Romaguera and Ostoic, 2004). The government did provide funding for some private schools before the 1980s, but the reform expanded this arrangement so much that it reached a point where there was no significant difference between the level of government funding provided to private and public schools. Later on, however, institutionally based differences in working conditions for teachers did arise, as did differences in the schools' organizational structures and, ultimately, their funding. The resulting difficulty of drawing direct comparisons between the performance levels of students in the different types of schools has sparked a heated debate about school administration and its effect on scholastic achievement.

One of the central hypotheses put forward in the vast body of literature that has grown up around this issue is that the private schools are better-run. This proposition is primarily based on the sharp differences between the unconditioned scores on standardized tests of students in the different types of schools. The ensuing public debate has focused on the sustainability of public education, especially in view of the fact that, as a percentage of the total, the $80 \%$ public school enrolment rate registered in 1980 had dropped to less than $45 \%$ by 2010 and that this steep reduction could be the result, at least in part, of the declining quality of the education being provided by the country's municipalities, where inter-school segmentation, admissions screening and

We would like to thank the Ministry of Education for having provided us with access to the System for Measuring the Quality of Education (SIMCE) database and to Rómulo Chumacero, Alejandro Carrasco, Cristián Cox, Alejandra Mizala, Paulo Volante and, in particular, a CEPAL Review referee for their comments and suggestions. We are also grateful for the funding supplied by the National Fund for Scientific and Technological Development (FONDECYT) under Project No. 1095176 and by the Centre for the Study of Educational Policy and Practice (CEPPE) under the CIE01 project of the National Commission for Scientific and Technological Research (CONICYT). Any errors or omissions in this article are the sole responsibility of the authors. inequities are raising some doubts about the success of the earlier reforms. ${ }^{1}$

The fact that sharp unconditioned differences are systematically found between the scores on standardized tests of students in one type of school or the other is not a sufficient basis for concluding that the quality of instruction provided by these schools differs, however. The view in some quarters is that the reform has led to a sharper stratification of the education system, with the most vulnerable students being left in the public schools, and that this accounts, at least in part, for the gap (Hsieh and Urquiola, 2006). As discussed in a number of studies, this view has fuelled the controversy surrounding the quantification of these differences in terms of production functions of education. The findings have varied, with some authors arriving at conclusions that are diametrically opposed to those of others: some have determined that subsidized private schools are turning in better performances; others have found no statistically relevant differential; and still others (after isolating a number of factors) have argued that public schools are the best performers. An additional factor to be taken into account is that there are also sharp differentials between one public school and the next (Paredes and Paredes, 2009).

The public policy implications of each of these different findings are, naturally, quite different. Gallego (2002), for example, contends that, despite the lack of any clear-cut difference between the scholastic achievement of pupils in municipal schools and those in subsidized private schools, the system in general has benefited from the increased competition and has consequently improved. Hsieh and Urquiola (2006) argue that the better results exhibited by subsidized private schools are primarily attributable to selection effects rather than to better administration. These differing positions are reflections of discussions that are taking place at differing levels, however. While the former position is taking an equilibrium analysis approach, the latter is not necessarily tackling the question from the same vantage point. Thus, even if private education were to prove to

\footnotetext{
1 For a discussion of these issue, see Hsieh and Urquiola, 2003; Paredes and Pinto, 2009; Chumacero and Paredes, 2009; and Marcel and Raczinsky, 2010.
} 
be "more efficient" than public education, this could be due to a student selection effect, and the underlying overall effects therefore cannot be identified unless a comprehensive study is conducted. The debate in Chile is thus centred on the point of departure, since the main point at issue at this juncture is whether or not such a gap actually exists at all. ${ }^{2}$

The purpose of this study is to delimit the discussion concerning empirical results by means of a meta-analysis. Meta-analyses are a tool that is widely used in the social sciences to distil and differentiate among the hypotheses put forward by many different studies when they fail to arrive at an agreed conclusion. It is only recently being applied in the field of education, however (e.g., Adesope and others, 2010; Credé, Roch and Kieszczynka, 2010; and Bowman, 2010). Based on a very strict adherence to the eligibility standards put forward by Raudenbush and Bryk (2002), 17 studies on the efficiency differences between private and municipal schools in Chile were selected. A robust statistical model was then used to check whether the results of the meta-analysis fit in with a general, robust specification and estimation method.

Four sections follow this introduction. Section II provides a description of the Chilean education system. Section III outlines the methodology that was used and describes the studies that were selected for the metaanalysis. Section IV presents the results. The conclusions are set forth in section V.

\section{II}

\section{The Chilean education system}

\section{Background}

Until the early 1980 s, nearly $80 \%$ of the country's schools were run by the State. The Ministry of Education was in charge of funding and running Chile's schools, supervising and developing curricula, and investing in and building public school infrastructure. The system had high dropout and repeater rates, however, and was viewed as delivering a poor-quality education owing to its excessively bureaucratic nature, insufficient coverage and failure to provide schools with proper incentives. ${ }^{3}$ This gave rise to a far-ranging reform of the education system based on the work done by Friedman (1955). Chile was one of the first countries in the world to introduce a reform of this type, or at least a reform of this scale and nature. State-run schools were handed over to the country's municipalities and were financed with subsidies that did not differentiate between pupils attending municipal schools and those attending nonfee private voucher schools (Mizala and Romaguera

\footnotetext{
2 The authors wish to thank the referee of the CEPAL Review for raising this point.

${ }^{3}$ Hanushek (1998) indicates, for example, that, in 1970, the test scores for Chile's students were 50\% lower than the those of students in France and the United States and 20\% lower than those of students in Japan and were only $10 \%$ higher than students in India and the Islamic Republic of Iran. Barro (1999) reported that Chile's scores were 50\% lower than what they would be expected to be given its level of development. For a detailed analysis, see Paredes and Hayl (2010).
}

1998). The reform gave rise to three types of schools: (i) municipal, State-funded schools (with funding provided by per-student subsidies); ii) privately run, State-funded subsidized schools (with funding provided by per-student subsidies); and (iii) privately run schools funded by tuition payments.

In order to make the education system better and more equitable so as to benefit the more vulnerable sectors of the population, in the early 1990s a number of programmes were put in place to supplement the school subsidy scheme, including special support programmes for schools serving underprivileged children (e.g., the "900 Schools" programme for poor sectors of the population, the Education Improvement Project and the Quality and Equity in Education Programme). ${ }^{4}$ In 1991 the Teachers Statute, which re-established teacher benefits that had been withdrawn in the 1980s, was passed. Among other things, it re-introduced collective negotiations on wages and on job security for the faculty of municipal schools. Apart from the advantages of this agreement, however, the Teachers Statute has heightened the differences between one education system and another by making the administrative arrangements for municipal schools more rigid. In 1996 an incentive system - the National Performance Evaluation System

\footnotetext{
4 The reasons why the effort to achieve greater equity takes the form of programme implementation rather than modifications of the subsidy are explained in Weinstein and Muñoz (2009). See also Weinstein, Fuenzalida and Muñoz (2010).
} 
(SNED) - was put in place in order to recognize and enhance teachers' best practices.

In 1993 a new provision was introduced to supplement State funding. Under this statute, some of the subsidized schools were allowed to charge parents for a portion of the tuition, and subsidized private schools and some public schools were authorized to receive donations or grants, which would be deducted from the State subsidy. ${ }^{5}$ This led to a steep rise in private school enrolment that has cast some doubt over the sustainability of the municipal school system (Paredes and Pinto, 2009).

These policies succeeded in bringing about a steep reduction in dropout rates and a steady increase in enrolment rates. The scores on the System for Measuring the Quality of Education (SIMCE) tests, however, indicate that the quality of education remains quite limited and that striking differences between the performance of students in different socio-economic sectors continue to pose a major challenge. ${ }^{6}$ Hsieh and Urquiola (2003) argue that the reform spurred an exodus of middle-class students from municipal schools to private subsidized ones, which left the municipal schools with a much greater proportion of students from vulnerable sectors and therefore drove down their average scores. Along these same lines, Mizala, Romaguera and Ostoic (2004) point out that municipal schools, unlike their private counterparts, have to accept all applicants (as long as they have room) and that it is quite difficult from them to expel students.

The consensus view is that these three types of schools are serving sharply stratified socio-economic groups. As shown in table 1, the majority of students in

TABLE 1

\section{Enrolment, by type of school \\ (Percentages)}

\begin{tabular}{lrrrrr}
\hline & \multicolumn{5}{c}{ Income quintile } \\
\cline { 2 - 6 } Type of school & \multicolumn{1}{c}{ I } & \multicolumn{1}{c}{ II } & III & IV & \multicolumn{1}{c}{ V } \\
\hline Municipal & 42.39 & 27.60 & 16.06 & 10.66 & 4.24 \\
Private (subsidized) & 22.34 & 22.63 & 21.26 & 20.59 & 13.37 \\
Private (fee-paying) & 4.64 & 4.64 & 4.49 & 12.37 & 75.26
\end{tabular}

Source: Prepared by the authors on the basis of the 2006 National Characterization Socio-economic Survey (CASEN) database.

\footnotetext{
${ }^{5}$ Secondary municipal schools can opt for the co-financing system if authorized to do so by a majority of parents and guardians.

${ }^{6}$ Chilean students scored substantially higher on the 2006 Programme for International Student Assessment (PISA) test, especially in the humanities (OECD, 2008). The reason for this improvement would be a highly interesting research topic.
}

municipal schools are from the lower-income quintiles (70\%), and this has been the situation for a number of years now. In contrast, subsidized private schools receive a larger percentage of middle-income students and even a considerable number of students from highincome sectors.

The overall results are not good either. The principal performance indicator for education in Chile is the standardized SIMCE test, and the scores on that test are much higher in fee-paying private schools than they are in the other two types of educational establishments. ${ }^{7}$

\section{Context and results}

Once the reform had been carried out, questions began to arise as to its repercussions and implications for the quality of education. One way of approaching this issue, which, although not a study of the reform's overall effects, could shed some light on one of its direct repercussions, is to analyse the performance differentials between municipal and subsidized private schools. There have been a plethora of studies on the subject in recent years, but they have arrived at very different conclusions, and this has added fuel to the debate over the years in ways that have often steered it into the realm of differing ideologies.

The conceptual and empirical foundations underlying this discussion clearly extend beyond the specific case of Chile. Hanushek (2003) suggests that, in recent years, the cost of public education has risen sharply without attaining the expected results. Chubb (2001) contends that, if education were privatized, schools would have powerful incentives for cutting costs and that this would push them to innovate and become more efficient. Others argue that this type of system would prompt private schools to cut costs in ways (e.g., recruiting less qualified teachers at lower salaries) that would lower the quality of the education that they provide. In addition, this system could lead to discriminatory practices whereby schools would give preference to students that would be less costly for them (Levin, 2002). In Hoxby's view (2001), this kind of situation arises because, in a flat-rate subsidization system, subsidized private schools have no incentive to take on students who are in more vulnerable situations, since they will require a larger investment in order to achieve better scores.

Chile's case is alluded to indirectly by Gallego (2002), who has developed a model for determining the effect of competition between municipal and subsidized

\footnotetext{
${ }^{7}$ For further information on the scores, see www.simce.cl
} 
private schools. Gallego finds a positive correlation between competition and performance, particularly in subsidized private schools, and interprets this as being a consequence of the existence of stronger incentives for a rapid response to potential competition. This would also, however, have a positive impact on municipal schools. Sapelli (2003), while working to draw general lessons from these experiences, talks about a form of market duality, inasmuch as Chile's public schools and subsidized private schools are not subject to the same external rules. Municipal schools, unlike their subsidized private counterparts, are subject to "soft" budgetary constraints in the sense that they often receive additional funding from the municipality, which is a disincentive for more efficient operations. On the other side, subsidized private schools have the option of obtaining more funding from the students' parents. Carnoy (1997) questions the idea that competition will have a positive effect and instead argues that such a system will only benefit higher-income students because, if schools are in competition with one another, they will try to select for the top students.

Valenzuela, Bellei and de los Ríos (2008) find that the crucial issue in Chile's education system is the striking differentials between the scores of students in the different types of schools, which are closely correlated with household income. Tokman (2002) finds that, following the reform, the municipal system lost its best students, who transferred to subsidized private schools, which lowered public schools' scores. By the same token, Hsieh and Urquiola (2006) state that, after the reform, the private subsidized schools' better showing was primarily due to the fact that they had selected out the best students.

Fontaine (2003) maintains that the use being made of the co-financing arrangement attests to the fact that many parents are willing to cover part of their children's educational costs if this will provide them with a higherquality education and more individual attention. In addition, subsidized private schools are required to use $10 \%$ of their tuition proceeds to provide scholarships for poor students, which clearly is of great benefit for poorer sectors of the population. Given the highly stratified nature of the education system, Tokman (2002), Carnoy (1997) and, in particular, McEwan (2003) all contend that the poorer performance of students in municipal schools is attributable to a peer effect (i.e., when less gifted students are grouped together, they are less likely to do well scholastically). This last proposition is open to discussion, since it has not been definitively resolved. There are, for example, schools of thought according to which this factor is irrelevant, and the segregation of students by abilities allows educators to use specific techniques that are geared towards overcoming their limitations.

The above discussion highlights the fact that a comparison of the performance of students in fee-paying private, subsidized private and municipal schools is a complex proposition. A series of studies have been conducted in an effort to assess relative performance levels using econometric models that are designed to take all the various factors affecting student performance into consideration. The choices made when selecting the operational approach, the variables to be taken into account and the estimation methods to be used are also, however, part of the discussion. As noted by Bellei (2005), the findings of studies designed to answer the question as to whether subsidized private education is better are determined, to a great extent, by the research methodology that they use, since quite small changes can have a strong impact on their ultimate results. 


\section{III}

\section{Methodology and data}

\section{Meta-analysis}

Meta-analysis is a technique for reviewing and aggregating the findings of different studies in an attempt to answer a given scientific question (Letón and Pedromingo, 2001). It began to come into use in the social sciences and agriculture in the 1930s. The term "meta-analysis" was coined by Glass (1976) and, since the 1980s, its use has become widespread, especially in the field of medicine and the social sciences. The greatest advantage that it offers is that it provides a way of determining how a number of different studies tie in with one another (Lipsey and Wilson, 2001), which, in turn, makes it possible to arrive at an overarching conclusion concerning any given hypothesis by first determining what the strengths and weaknesses of each study are and why their findings differ.

More recently, meta-analysis has come into use in the field of education. Adesope and others (2010) have used it to estimate the effect of bilingualism on cognitive outcomes. Credé, Roch and Kieszczynka (2010) have used it to determine the correlations between students' grades and class attendance. Bowman (2010) has employed the methodology to try to establish a relationship between a school's racial diversity and its students' cognitive development.

A meta-analysis has two stages: (i) compiling relevant studies, and (ii) relating the selected studies to one another. In the compilation stage, a formal set of selection criteria has to be established in order to minimize the bias generated by the choice of studies. In the case at hand, the selection criteria are: (i) that the studies refer either directly or indirectly to differences in academic performance between public and private schools in Chile; (ii) that they were published after 1997 (so as to limit the range of studies to the more recent ones); (iii) that they have had a fairly notable impact in the field, as measured by the stature of the publisher or the number of times that they have been cited in other research papers; (iv) that their estimates have been arrived at through the use of econometric models; and (v) that they have used representative datasets.

The techniques used in the second stage of a metaanalysis are classical statistical methods. Meta-analyses are used for statistical inference, measurement of the overall effect size, variance estimation, confidence intervals, and statistical contrast and its significance.

The methodology for relating a set of studies to one another is based on the model proposed by Raudenbush and Bryk (2002), who used hierarchical linear modelling (HLM) to obtain the mean and overall variance of the parameter to be estimated. It makes sense to use HLM because of the nested structure of the variables in question. The model has two levels. The first is related to each study's results and their variance, while the second refers to the overall parameter to be estimated (the parameter being sought) and the variance among the studies being analysed. The first step is to obtain the standardized mean of the effect to be analysed for each study included in the meta-analysis, which is represented by $d_{j}$. For study $j$, this is obtained by (1). Thus, for the $j$-nth study, $d_{j}$ is expressed by the following equation:

$$
d_{j}=\frac{\bar{Y}_{E j}-\bar{Y}_{c j}}{S_{j}}
$$

where $\bar{Y}_{E j}$ is the mean for the experimental group; $\bar{Y}_{c j}$ is the mean for the control group; and $S_{j}$ is the standard deviation of the difference between the two. Equation (1) yields a standardized value for the standard deviation for each study, thereby assigning a greater weighting to studies with less variability.

At the first level, the model is:

$$
d_{j}=\delta_{j}+e_{j}, \quad e_{j} \sim N\left(0, V_{j}\right)
$$

For each study $j, e_{j}$ is the error associated with the variable $d_{j}$. The statistical distribution of $e_{j}$ is a normal one with a mean of 0 and a variance of $V_{j}$, while $\delta_{j}$ corresponds to the real value of the variable in study $j$. In this case, the relevant variable (linked to the parameter "subsidized private school") obtained from each study is $d_{j}$, and its corresponding variance is $V_{j}$ (both known values). At the second level, a similar model is used:

$$
\delta_{j}=\gamma_{0}+u_{j}
$$


where:

$\gamma_{0}$ is the overall mean, and

$u_{j}$ is the error at the second level, which distributes $u_{j} \sim N(0, \tau)$.

Thus, by introducing equation (3) into (2), for each study we obtain the final model:

$$
d_{j}=\gamma_{0}+u_{j}+e_{j}
$$

Therefore, $d_{j}$ distributes normally $d_{j} \sim N\left(\gamma_{0} \cdot \tau_{0}+V_{j}\right)$. This yields the overall parameter $\left(\gamma_{1} 0\right)$ and the overall standard deviation $\left(\tau_{0}\right)$. It is possible to estimate whether $\tau_{0}$ is actually statistically different from 0 so that we can then determine if a relevant difference exists among the selected studies. To do so, we use a hypothesis test where $H_{0}: \tau_{0}=0$, with the statistic:

$$
Q=\sum V_{j}^{-1}\left(d_{j}-d .\right)^{2}
$$

where $\bar{d} .=\sum V_{j}^{-1} *_{j} / \sum V_{j}^{-1}$. This statistic has a distribution of $\chi^{2}$ with $j$-1 degrees of freedom, while $Q$ is the term discussed by Hedges (1982). To estimate $\delta_{j}$ (Bayes estimator), the steps involved are as follows: on the one hand, $\bar{Y}_{. j}$ is an unbiased estimator of $\delta_{j}$ with a variance of $V_{j}$, but, on the other, $\gamma_{0}$ can be regarded as a common estimator for each $\delta_{j}$. The optimum estimator for each study can be calculated using the optimum Bayes estimator $\left(\delta_{j}^{*}\right)$ (Lindley and Smith, 1972), since it combines the two parameters discussed above in an optimum manner:

$$
\delta_{j}^{*}=\lambda_{j} \bar{Y}_{. j}+\left(1-\lambda_{j}\right) \hat{\gamma}_{0}
$$

where $\lambda_{j}$ is equal to the reliability of $\bar{Y}_{\cdot j}$ as an estimator of $\delta_{j}$.

$$
\lambda_{j}=\frac{\operatorname{Var}\left(\delta_{j}\right)}{\operatorname{Var}\left(\bar{Y}_{. j}\right)}=\frac{\tau_{0}}{\left(\tau_{0}+V_{j}\right)}
$$

From (7) it can be inferred that, when the sample is highly reliable, there will tend to be a marked preponderance of $\bar{Y}_{\cdot j}$ in the value of $\delta_{j}^{*}$, given its proximity. This means that $\lambda_{j}$ will have a value close to 1. If, on the other hand, the sample is not reliable, $\hat{Y}_{0}$ will tend to have a greater weight in the value of $\delta_{j}^{*}$, while $\lambda_{j}$ will tend towards a value close to 0 .

\section{Selected studies and data}

A total of 17 studies were selected. These studies use a nationwide sample of SIMCE test scores to estimate the effect by means of multiple regressions using ordinary least squares (OLS), the Heckman correction (HC), propensity score matching (PSM) or hierarchical linear modelling (HLM). The most complete model in which the estimates and conclusions were the most coherent was used for each study. Of course, given the differences in the models, bases, levels of aggregation, specifications and estimation techniques used in the various studies, their results are not the same. And this is precisely what the meta-analysis is intended to address. Table 2 shows that the biggest differences are in the year, grades and subjects used for the sample. The models' levels of aggregation also differ, since some studies worked at the school level and others at that of individual students. The study samples vary as well, while screening differences and a lack of data in some cases could account for part of the differences in their results. Imputation methodologies can, of course, also explain inter-study differences.

The methodologies used also differed. In the first generation of studies -Mizala and Romaguera (1998); Bravo, Contreras and Sanhueza (1999); McEwan and Carnoy (2000); Gallego (2002); Tokman (2002); and Sapelli (2003) — the results were analysed while controlling for individual, family and geographic factors at the school level. OLs were used to estimate an educational output function; no consensus was reached, although subsidized private schools did tend to yield somewhat more favourable results. These studies suffer from a number of limitations, however, with the main one being that their data were compiled at the school level, which did not allow them to look at within-school variations.

The second-generation studies were conducted at the level of individual students using OLS and HC models: McEwan, 2001; González, Mizala and Romaguera, 2002; Sapelli and Vial, 2002; Bellei, 2005; Contreras, Bustos and Sepúlveda (2007); and García and Paredes, 2010. McEwan (2001), Contreras, Bustos and Sepúlveda (2007) and García and Paredes (2010) took the endogeneity of school choice into consideration to some degree and Heckman-corrected their oLs models. Mizala and Romaguera (2003), Manzi and others (2008) and Mizala, Romaguera and Ostoic (2004) based their estimates on two-level HLM models so as to address the heterogeneity of students attending different schools.

Each study controls for different variables, although they almost all share a certain number of them. The 
TABLE 2

Datasets for each study

\begin{tabular}{|c|c|c|c|c|}
\hline Study & Year/grade/subject ${ }^{\mathrm{a}}$ & Level & Model & Sample ${ }^{b}$ \\
\hline Mizala and Romaguera (1998) & 1996/4thE/M and L & School & OLS & $5133(63.3 \%)$ \\
\hline Bravo, Contreras and Sanhueza (1999) & 1996/4thE/M & School & OLS & $5110(63.0 \%)$ \\
\hline McEwan and Carnoy (2000) & 1996/4thE/M & School & OLS & $5490(67.7 \%)$ \\
\hline McEwan (2001) & 1997/4thE/M & Student & $\mathrm{HC}$ & $158872(67.4 \%)$ \\
\hline Gallego (2002) & 1996/4thE/M and L & School & OLS & $4904(62.9 \%)$ \\
\hline González, Mizala and Romaguera (2002) & 1999/4thE/M & Student & OLS & $202754(88.8 \%)$ \\
\hline Sapelli and Vial (2002) & $1998 / 2 \mathrm{ndS} / \mathrm{L}$ & Student & $\mathrm{HC}$ & $46223(25.2 \%)$ \\
\hline Tokman (2002) & 1996/4thE/M & School & OLS & $2789(37.2 \%)$ \\
\hline Sapelli (2003) & 1999/4thE/M & School & OLS & $4784(61.5 \%)$ \\
\hline Mizala and Romaguera (2003) & 1998/2ndS/M & Student & HLM & $69402(30.9 \%)$ \\
\hline Mizala, Romaguera and Ostoic (2004) & 1999/4thE/M & Student & HLM & $226860(83.5 \%)$ \\
\hline Bellei (2005) & 2002/4thE/M & Student & OLS & $199112(83.3 \%)$ \\
\hline Contreras, Bustos and Sepúlveda (2007) & 2005/4thE/M & Student & $\mathrm{HC}$ & $161619(61.1 \%)$ \\
\hline Manzi and others (2008) & 2005/4thE/M & Student & HLM & $233338(88.2 \%)$ \\
\hline Mizala, Anand and Repetto (2009) & 2002/4thE/L & Student & PSM & $77921(32.6 \%)$ \\
\hline García and Paredes (2010) & 2005/4thE/M & Student & $\mathrm{HC}$ & $225206(85.1 \%)$ \\
\hline Mizala, Repetto and Lara (2009) & 2006/2ndS/M & Student & PSM & 20000 aprox. $^{\mathrm{c}}$ \\
\hline
\end{tabular}

Source: Prepared by the authors.

a Year, grade (E: elementary, S: secondary) and subject (L: language, M: mathematics) are characteristics of the datasets of simce scores used to develop the models.

b For the studies conducted at the school level, the size of the sample corresponds to the number of schools that were surveyed. For the studies conducted at the student level, the sample size corresponds to the number of individual students in that sample, but it will differ enormously depending on data imputations or the criteria used to eliminate observations in which data were missing.

c In this case, samples from different years were used.

OLS: ordinary least squares. HC: Heckman correction. HLM: hierarchical linear modelling. PSM: propensity score matching.

third column of table 3 shows the variables included in each model. All the studies control for socio-economic characteristics, although the specific variable changes from one to the next (for example: vulnerability index, linear income, quadratic income). Socio-economic status is systematically approximated by the parents' level of education, either at the average level per school or for individual students, depending on the nature of each model. Table 3 shows the results for each of the 17 studies. Ten of the studies suggest that subsidized private schools provide a better education; five find no statistically significance difference, and two indicate that municipal schools offer a better-quality education.

The variation in these results is quite striking, with conditioned differences ranging from -6.948 to 18.107 , with a mean standard deviation of 6.338 . Both the mean (4.358) and the median (3.431) are positive, which suggests that most of the studies point to a better performance on the part of subsidized private schools than municipal schools.

In summary, there are some variables that have been used in almost all of the studies, while there are others that have been used in only one or a few (e.g., sex of the student, presence of indigenous students) (for a detailed description, see Drago, 2010). No clear relationship between the types of control variables and differences in performance outcomes for municipal and subsidized private schools emerges, however. Nonetheless, there does appear to be a difference in terms of the number of controls, especially in the case of fixed effects identified by HLM, in which case the difference, in either direction, declines. 


\section{Characteristics of the selected studies}

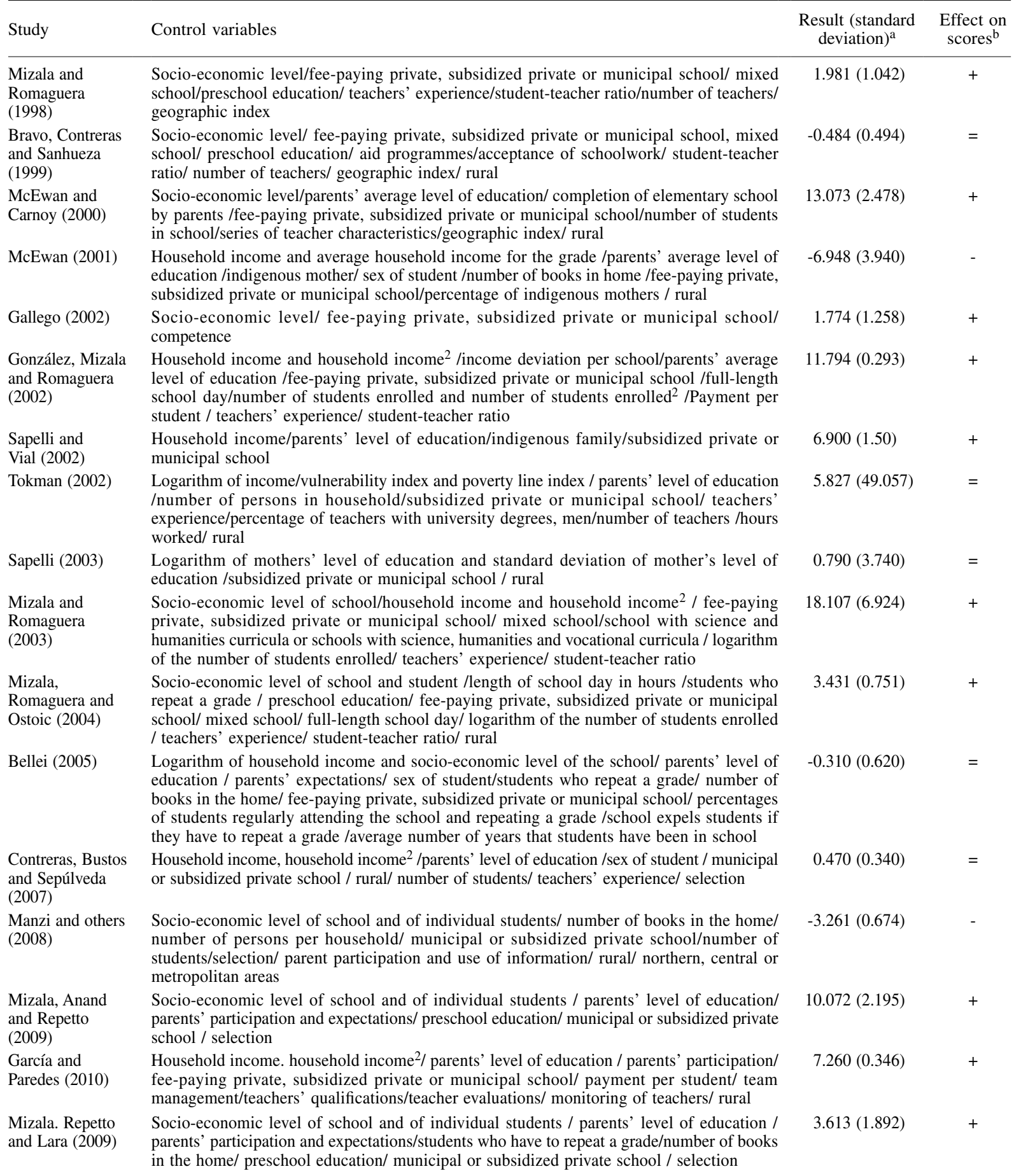

Source: Prepared by the authors.

a Differences (in points) in SIMCE scores calculated in each study; positive values indicate a better outcome for subsidized private schools while negative values indicate a better outcome for municipal schools.

b +: positive effect for subsidized private education; =: no statistically significant difference; -: negative effect for subsidized private education (90\% significance). 


\section{IV}

\section{Results}

\section{Meta-analysis}

The results of the meta-analysis are presented in table 4 . The figures show that subsidized private schools out-perform municipal schools by 3.9 points, with a confidence interval of $95 \%$. The same table also shows that the standard deviation between studies is 5.9, which indicates how sensitive the selected models are to the datasets used and their specification. Once again, a homogeneity test of this parameter rules out the homogeneity hypothesis $(\mathrm{p}<0.01)$.

Figure 1 provides a clearer picture of the results of the meta-analysis and of the different studies. For each study, a numerical value is given on the horizontal axis for each coefficient of the dummy variable for a subsidized private school (relative to a municipal school) and the respective confidence interval. Each study is represented by a square whose size corresponds to its weighting in the meta-analysis, which bears a direct relationship to the precision of each estimator, and by a horizontal line that shows the confidence interval of the estimator (the greater the quotient of the estimator and its variance, the greater that study's weighting). The rhombus at the bottom represents the estimated value yielded by the meta-analysis of all the studies (3.923), while the distance between the horizontal sides represents the standard deviation of that estimate. The dotted vertical line rising from the rhombus provides a point of reference for gauging how the estimate for each study compares to the overall estimate.

The optimum Bayes estimators, i.e., the estimator for each study corrected by the overall estimated effect, can also be obtained (see table 5).

TABLE 4

Results of the meta-analysis for all of the selected studies

\begin{tabular}{ccccccc}
\hline Overall parameter & Minimum value & Maximum value & Standard deviation & Q (homogeneity test) & Value $p$ \\
\hline 3.923 & 0.851 & 6.996 & 5.900 & 942.200 & 0.000 \\
\hline
\end{tabular}

Source: Prepared by the authors.

FIGURE 1

Graphic representation of the meta-analysis results

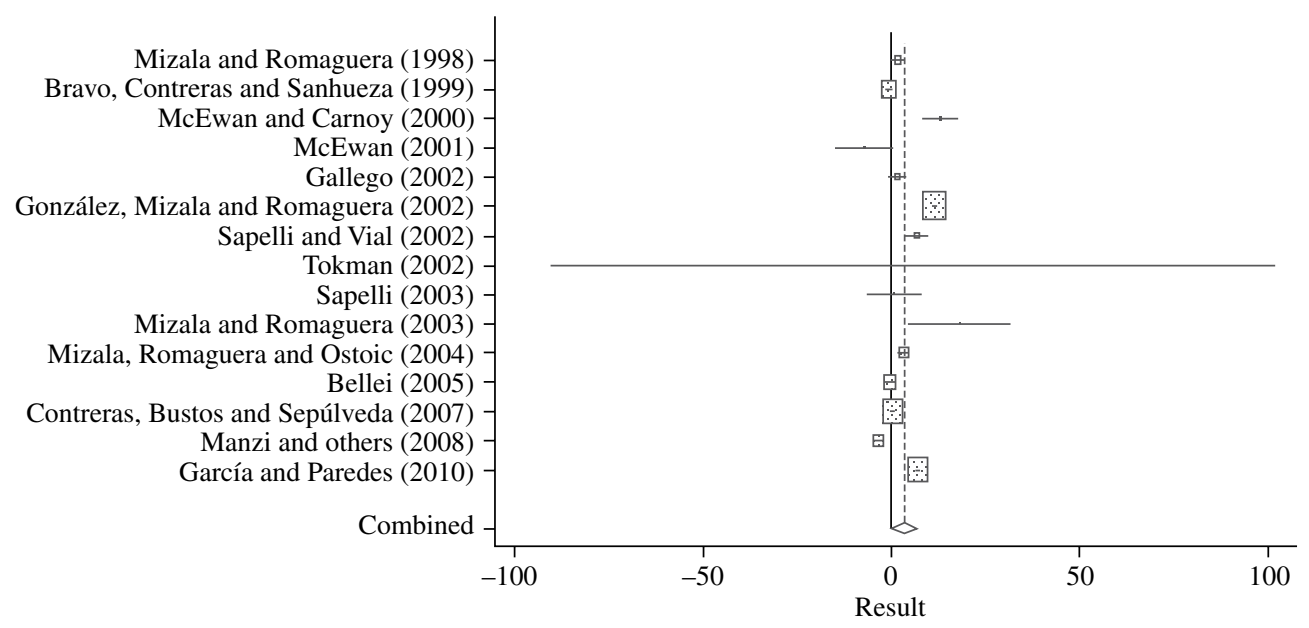

Source: Prepared by the authors. 


\begin{tabular}{lrrr}
\hline Study & Result & Corrected result & Minimum \\
\hline Mizala and Romaguera (1998) & 1.981 & 2.030 & 0.340 \\
Bravo, Contreras and Sanhueza (1999) & -0.494 & -0.430 & -1.270 \\
McEwan and Carnoy (2000) & 13.073 & 11.580 & 7.820 \\
McEwan (2001) & -6.948 & -3.630 & -9.050 \\
Gallego (2002) & 1.774 & 1.850 & -0.170 \\
González, Mizala and Romaguera (2002) & 11.800 & 11.770 & 11.270 \\
Sapelli and Vial (2002) & 6.900 & 6.680 & 4.290 \\
Tokman (2002) & 5.827 & 3.880 & -6.290 \\
Sapelli (2003) & 0.790 & 1.50 & -3.640 \\
Mizala and Romaguera (2003) & 18.107 & 9.080 & 2.010 \\
Mizala, Romaguera and Ostoic (2004) & 3.431 & 9.470 & 2.30 \\
Bellei (2005) & -0.310 & 3.430 & -210 \\
Contreras, Bustos and Sepúlveda (2007) & 0.470 & -0.270 & -1.280 \\
Manzi and others (2008) & -3.261 & 0.48 & -0.080 \\
García and Paredes (2010) & 7.260 & -3.170 & -4.270 \\
\hline
\end{tabular}

Source: Prepared by the authors.

\section{A more robust specification}

In order to determine how much the results of the metaanalysis may have been influenced by the rigidity of the specifications, a model can be estimated using the most robust possible structure. At the same time, we can use both oLS and HLM estimates in order to check whether or not the results are sensitive to the method chosen. In other words, if the results obtained after estimating a model using two different methods - OLS and HLMwith a highly robust specification (without any bias due to the omission of variables) differ by something on the order of 4 points, then the controversy could be attributable to a specification problem, rather than to the grade chosen or the screening of the sample. If, however, they differ by an amount that is substantially different from the results of the meta-analysis, then the controversy about the reasons for this difference continues, although the nature of the point at issue can be defined somewhat more precisely. The scores on the SIMCE math test for students in the fourth grade in 2008 will be used for this purpose.

One particularly interesting aspect in this case is that the robust specification takes selection variables into account, since selection is presumably more of a factor in subsidized private schools than in municipal ones. And, in fact, $67 \%$ of the subsidized private schools report that they do practise some sort of admissions screening, whereas, for municipal schools, the figure is $37 \%$. We therefore include a set of interactive terms that also make the estimate more robust.

In sum, the specification for the two-level HLM model is as follows. At the student level:

$$
\begin{gathered}
Y_{i j}=\beta_{0 j}+\beta_{1 j} \operatorname{Ln}\left(g_{i j}\right)+\beta_{3 j} \operatorname{EdPad}_{i j}+\beta_{4 j} \operatorname{EdMad}_{i j}+ \\
\beta_{5 j} \operatorname{EdPresCol}_{i j}+\beta_{6 j} \operatorname{Gen}_{i j}+\beta_{7 j} \operatorname{MadInd}_{i j}+ \\
\beta_{8 j} N^{0} \operatorname{Hab}_{i j}+\beta_{9 j} \operatorname{EspPad}_{i j} r_{i j}
\end{gathered}
$$

where $Y_{i j}$ is the score on the SIMCE mathematics test of student $i$, who attends school $j . r_{i j}$ is the level-1 error term, which is distributed $r_{i j} \sim N\left(0, \sigma^{2}\right)$, where $\sigma^{2}$ represents the level-1 variance.

The model at the school level (level 2) is as follows:

$$
\begin{gathered}
\beta_{0 j}=\gamma_{00}+\gamma_{01} P S+\gamma_{02} P P+\gamma_{03} \text { Ln }(\text { SchSes })+ \\
\gamma_{04} \text { Urbano }+\gamma_{05} \text { TamClas }+\gamma_{06} \text { TamClas }^{2}+ \\
\gamma_{07} \text { Ln }(\text { ExProf })+\gamma_{08} \text { Selección }+\mu_{j 0}
\end{gathered}
$$

where $\gamma_{00}, \gamma_{01}, \ldots, \gamma_{08}$ are the level-2 coefficients. $\mu_{j 0}$ is the level-2 error term, which is distributed $\mu_{j 0} \sim N\left(0, \tau_{00}\right)$ and covariance $\tau_{00}$.

Four models are estimated using oLs and HLM; this permits different controls to be used (see table 6).

The results given in table 6 show that the fewer controls there are (model A), the greater the differential in favour of subsidized schools. These results, particularly in the case of the HLM model with more controls, are consistent with the results of the meta-analysis in that they show that subsidized private schools out-perform municipal schools. The differential yielded by this model is substantially greater than the differential suggested by the meta-analysis, however. This could be attributable -apart from possible factors such as aggregation- to the grade and year chosen. 
TABLE 6

Results of the application of OLS and HLM

to fourth-graders' SIMCE mathematics scores

\begin{tabular}{|c|c|c|c|c|}
\hline \multirow{2}{*}{ Variables } & \multicolumn{2}{|c|}{ OLS } & \multicolumn{2}{|c|}{ HLM } \\
\hline & Model A & Model B & Model C & Model D \\
\hline \multicolumn{5}{|l|}{ Student level } \\
\hline Constant & $224.49(0.311)^{*}$ & $181.76(1.08)^{*}$ & $230.39(0.37)$ & $186.73(1.08)^{*}$ \\
\hline Logarithm of income & & $1.46(0.18)^{*}$ & & $0.54(0.12)^{*}$ \\
\hline Education of father & & $0.55(0.13)^{*}$ & & $0.07(0.12)$ \\
\hline Education of mother & & $1.43(0.14)^{*}$ & & $0.49(0.13)^{*}$ \\
\hline Preschool education & & $4.78(0.25)^{*}$ & & $5.01(0.23)^{*}$ \\
\hline Sex & & $5.10(0.23) *$ & & $5.65(0.23) *$ \\
\hline Indigenous mother & & $-2.39(0.39)^{*}$ & & $-2.20(0.39)^{*}$ \\
\hline Parent expectations & & $8.43(0.89) *$ & & $7.78(0.84)^{*}$ \\
\hline Number of persons in household & & $-1.55(0.07)^{*}$ & & $-1.00(0.07)^{*}$ \\
\hline \multicolumn{5}{|l|}{ School level } \\
\hline Constant & & & $-20.19(0.36)^{*}$ & $-12.66(0.89)^{*}$ \\
\hline Subsidized private school & $21.71(0.23)^{*}$ & $7.20(0.30)^{*}$ & $22.22(0.80)^{*}$ & $10.53(1.27)^{*}$ \\
\hline Fee-paying school & $68.56(0.44) *$ & $30.93(0.62)^{*}$ & $59.47(2.50)^{*}$ & $48.33(2.82)^{*}$ \\
\hline Logarithm of socio-economic level & & $19.39(0.48)^{*}$ & & $12.66(0.67)^{*}$ \\
\hline Urban & $8.54(0.34)^{*}$ & $-15.77(0.43)^{*}$ & $7.01(1.13)^{*}$ & $-13.90(1.32)^{*}$ \\
\hline Class size & & $0.13(0.006)^{*}$ & & $0.23(0.08)^{*}$ \\
\hline Class size 2 & & $-0.004(0.002)^{*}$ & & $-0.002(0.001)$ \\
\hline Logarithm of teachers' experience & & $3.91(0.15)^{*}$ & & $4.32(0.31)^{*}$ \\
\hline Selection & & $0.40(0.25)$ & & $8.46(2.86)^{*}$ \\
\hline
\end{tabular}

Source: Prepared by the authors.

$*: p \leq 0.05$.

\section{Conclusions}

The discussion about the relative efficiency of public schools has been particularly intense in Chile, where private education is funded by the State under a scheme that is essentially the same as the arrangements in place for financing public education. The debate has been fuelled by differences in the amount of funding provided under the "shared financing" arrangement, the additional funding furnished by the municipalities, the possibility of admissions screening and the different employment regimes that have been instituted. This debate has also been spurred by the fact that different studies on the subject have offered up different conditioned results. The objective of this study has been to clarify the empirical issues by applying a meta-analysis to the 17 most influential studies on the subject. Our findings make it possible to delimit the speculation surrounding the actual difference in performance between private subsidized schools and municipal schools by gauging that difference at something on the order to 4 points. While this is in the neighbourhood of one tenth of the standard deviation of the achievement test in question, it nonetheless represents a significant difference from an educational standpoint, especially in view of the striking stability of school performance outcomes.

This analysis does not, of course, settle the question as to the role of public education. The fact that, on average, private education out-performs public education tells us little about what types of policies we need to introduce in order to benefit the very considerable percentage of students who attend municipal schools and have no real chance to transfer to another type of school. What these findings do suggest, however, is that attention should be focused on determining what practices and what constraints are holding back progress in the country's municipal schools.

(Original: Spanish) 


\section{Bibliography}

Adesope, O. and others (2010), "A systematic review and metaanalysis of the cognitive correlates of bilingualism", Review of Educational Research, vol. 80, No. 2, Washington, D.C., American Educational Research Association.

Aedo, C. and C. Sapelli (2001), "El sistema de vouchers en la educación: una revisión de la teoría y la evidencia empírica para Chile", Working Paper, No. 307, Santiago, Chile, Centro de Estudios Públicos.

Barro, R. (1999), "Determinants of economic growth: implications of the global evidence for Chile", Cuadernos de economía, vol. 36, No. 107, Santiago, Chile, Catholic University of Chile.

Bellei, C. (2005), The Private-Public School Controversy: the Case of Chile, Cambridge, Massachusetts, John F. Kennedy School of Government, Harvard University.

Bowman, N. (2010), "College diversity experiences and cognitive development: a meta-analysis", Review of Educational Research, vol. 180, No. 1, Washington, D.C., American Educational Research Association.

Bravo, D., D. Contreras and C. Sanhueza (1999), "Rendimiento educacional, desigualdad y brecha de desempeño público/ privado: Chile 1982-1997”, Working Paper, No. 163, Santiago, Chile, University of Chile.

Brunner, J. and others (2005), Educación preescolar: estrategias Bicentenario, Santiago, Chile, Ministry of Education.

Carnoy, M. (1997), "Is privatization through education vouchers really the answer? A comment on West", World Bank Research Observer, vol. 12, No. 1, Oxford, Oxford University Press.

Chubb, J. (2001), "The profit motive", Education Matters, vol. 1, Cambridge, Massachusetts, Education Matters.

Chumacero, R. and R. Paredes (2009), "Should for-profit schools be banned?", MPRA Paper, No. 15099, Munich, University Library of Munich.

Contreras, D., S. Bustos and P. Sepúlveda (2007), "Cuando los colegios son los que eligen: el efecto de la selección en Chile", Working Paper, Santiago, Chile, University of Chile.

Credé, M., S. Roch and U. Kieszczynka (2010), "Class attendance in college: a meta-analytic review of the relationship of class attendance with grades and student characteristics", Review of Educational Research, vol. 180, No. 2, Washington, D.C., American Educational Research Association.

Drago, J. (2010), "La educación en Chile: una revisión y meta-análisis de resultados", thesis, Santiago, Chile, Catholic University of Chile.

ECLAC (Economic Commission for Latin America and the Caribbean) (2001), Latin American and Caribbean Regional Plan of Action on Human Settlements (LC/G.2143), Santiago, Chile.

Fontaine, A. (2003), "Cuotas obligatorias de alumnos vulnerables en la educación subvencionada: antecedentes para la discusión", Puntos de referencia, No. 267, Santiago, Chile, Centro de Estudios Públicos.

Friedman, M. (1955), "The role of government in education", Economics and the Public Interest, R. Solo (comp.), New Brusnwick, Rutgers University Press.

Gallego, F. (2002), "Competencia y resultados educativos: teoría y evidencia para Chile", Cuadernos de economía, vol. 39, No. 118, Santiago, Chile, Catholic University of Chile.
García, C. and R. Paredes (2010), "Reducing the educational gap: good results in vulnerable groups", Journal of Developments Studies, vol. 46, No. 3, Taylor and Francis.

Glass, G. (1976), "Primary, secondary, and meta-analysis of research", Educational Researcher, No. 5, Washington, D.C., American Educational Research Association.

González, P., A. Mizala and P. Romaguera (2002), "Recursos diferenciados a la educación en Chile", Economía series, No. 150, Santiago, Chile, Centre for Applied Economics, University of Chile.

Hanushek, E. (2003), "The failure of input-based schooling policies", The Economic Journal, vol. 113, No. 485, Wiley.

(1998), "Conclusion and controversies about the effectiveness of school resources", Economic Policy Review, New York, Federal Reserve Bank of New York, March.

Heckman, J. (1978), "Sample selection bias as a specification error", Econometrica, vol. 47, No. 1, New York, Econometric Society.

Hedges, L. (1982), "Fitting continuous models to effect size data", Journal of Educational and Behavioral Statistics, vol. 7, No. 4, Washington, D.C., American Educational Research Association

Hoxby, C. (2001), School Choice and School Productivity. Could School Choice be a Tide that Lifts All Boats?, Cambridge, Massachusetts, National Bureau of Economics Research, February.

Hsieh, C. and M. Urquiola (2006), "The effects of generalized school choice on achievement and stratification: evidence from Chile's voucher program", Journal of Public Economics, vol. 90 , No. 8-9, Amsterdam, Elsevier.

(2003), "When schools compete, how do they compete? An assessment of Chile's nationwide school voucher program", NBER Working Papers, No. 10008, Cambridge, Massachusetts, National Bureau of Economics Research.

Letón, E. and A. Pedromingo (2001), Introducción al análisis de datos en meta-análisis, Madrid, Diaz de Santos Editores.

Levin, H. (2002), "Potential of for-profit schools for educational reform", Occasional Paper Series, No. 47, Columbia, Center for the Study of Privatization in Education, Teachers College.

Lindley, D. and V. Smith (1972), "Bayes estimates for the linear model", Journal of the Royal Statistical Society, Series B, vol. 34, No. 1, London, Royal Statistical Society.

Lipsey, M. and D. Wilson (2001), Practical Meta-Analysis, Thousand Oaks, Sage.

Manzi, J. and others (2008), Quality of Education in Chile, Santiago, Chile, Centro Medición MIDE UC.

Marcel, M. and D. Raczynski (2010), La asignatura pendiente, Santiago, Chile, Uqbar Editores.

McEwan, P. (2003), "Peer effect on student achievement: evidence from Chile", Economics of Education Review, vol. 22, No. 2, Amsterdam, Elsevier.

(2001), "The effectiveness of public, catholic, and nonreligious private schools in Chile's voucher system", Education Economics, vol. 9, No. 2, Taylor and Francis.

McEwan, P. and M. Carnoy (2000), "The effectiveness of public, catholic, and non-religious private schools in Chile's voucher system", Educational Evaluation and Policy Analysis, vol. 22, 
No. 3, Washington, D.C., American Educational Research Association.

MINEDUC (Ministry of Education) (2008), PISA 2006: rendimientos de estudiantes de 15 años en ciencias, lectura y matemática, Santiago, Chile.

Mizala, A. and P. Romaguera (2003), "Equity and educational performance", Working Paper, No. 136, Santiago, Chile, Centre for Applied Economics, University of Chile.

(1998), "Desempeño escolar y elección de escuelas: la experiencia chilena", Working Paper, No. 36, Santiago, Chile, Centre for Applied Economics, University of Chile.

Mizala, A., P. Anand and A. Repetto (2009), "Using school scholarships to estimate the effect of private education on the academic achievement of low-income students in Chile", Economics of Education Review, vol. 28, No. 3, Amsterdam, Elsevier.

Mizala, A., A. Repetto and B. Lara (2009), "The effectiveness of private voucher education: evidence from structural school switches", Working Paper, No. 263, Santiago, Chile, Centre for Applied Economics, University of Chile.

Mizala, A., P. Romaguera and C. Ostoic (2004), "Equity and achievement in the Chilean school choice system", Working Paper, No. 185, Santiago, Chile, Centre for Applied Economics, University of Chile.

OECD (Organisation for Economic Co-operation and Development) (2008), PISA 2006. Science Competencies for Tomorrow's World, Paris.

Paredes, R. and M. Hayl (2010), "Un diagnóstico sobre la calidad de la educación en Chile", Working Paper, Santiago, Chile, Catholic University of Chile.
Paredes, R. and V. Paredes (2009), “Chile: academic performance and educational management under a rigid employment regime", CEPAL Review, No. 99 (LC/G.2418-P), Santiago, Chile, December.

Paredes, R. and J. Pinto (2009), “EEl fin de la educación pública en Chile?”, Estudios de economía, vol. 36, No. 1, Santiago, Chile, University of Chile, June.

Raudenbush, S. and A. Bryk (2002), Hierarchical Linear Models: Applications and Data Analysis Methods, Thousand Oaks, Sage Publications.

Sapelli, C. (2003), "The Chilean voucher system: some new results and research challenges", Cuadernos de economía, vol. 40, No. 121, Santiago, Chile, Catholic University of Chile.

Sapelli, C. and B. Vial (2002), "The performance of private and public schools in the Chilean voucher system", Cuadernos de economía, vol. 39, No. 118, Santiago, Chile, Catholic University of Chile.

Tokman, A. (2002), "Is private education better? Evidence from Chile", Working Paper, No. 147, Santiago, Chile, Central Bank of Chile

Valenzuela, J., C. Bellei and D. de los Ríos (2008), Evolución de la segregación socioeconómica de los estudiantes chilenos y su relación con el financiamiento compartido, Santiago, Chile, Ministry of Education.

Weinstein, J. and G. Muñoz (2009), "Calidad para todos. La reforma educacional en el punto de quiebre", Más acá de los sueños, más allá de lo posible: la Concertación en Chile, Bascuñan and others (comps.), vol. II, Santiago, Chile, LOM.

Weinstein, J., A. Fuenzalida and G. Muñoz (2010), "La subvención preferencial: desde una difícil instalación hacia su institucionalización", in press. 